\title{
PENGARUH DRAMA KOREA TERHADAP FASHION MAHASISWA UNIVERSITAS AL ASYARIAH MANDAR
}

\author{
Nurrahmadani', Sri Yuyun², Munawi Gay ${ }^{3}$ \\ ${ }^{1}$ Prodi Ilmu Komunikasi, Fakultas Ilmu Sosial dan Ilmu Pemerintahan \\ Universitas Al Asyariah Mandar \\ Email: nurrahmadany02@gmail.com \\ ${ }^{2}$ Prodi Ilmu Komunikasi, Fakultas Ilmu Sosial dan Ilmu Pemerintahan \\ Universitas Al Asyariah Mandar \\ Email: yuyunsri765@gmail.com \\ ${ }^{3}$ Prodi Ilmu Komunikasi, Fakultas Ilmu Sosial dan Ilmu Pemerintahan \\ Universitas Al Asyariah Mandar \\ Email: nawir1463@gamil.com
}

\begin{abstract}
$\operatorname{ABSTRACT}$
This study aims to determine the effect of Korean drama on student fashion at Al Asyariah Mandar University. The research uses a quantitative approach, using purposive sampling technique. The data obtained through questionnaires (skalah liker) and the method of analysis of data determination $(R)$. The results showed that there was an influence of Korean drama on student fashion by $33 \%$ (coefficients of detemination) while the remaining $67 \%$ was influenced by other variables not in this study.
\end{abstract}

\section{ABSTRAK}

Penelitian ini bertujuan untuk mengetahui pengaruh Drama Korea terhadap fashion mahasiswa Universitas Al Asyariah Mandar. penelitian menggunakan pendekatan kuntitatif, Dengan menggunakan teknik purposive sampling. data yang diperoleh melalui kuisioner (skalah liker) serta metode analisis data determinasi (R). Hasil penelitian memperlihatkan terdapat pengaruh drama Korea terhadap fashion mahasiswa sebesar 33\% (koevisien deteminasi) sedangkan sisanya sebanyak $67 \%$ dipengaruhi oleh variabel-variabel lain yang tidak ada di dalam penelitian ini.

Kata Kunci: Drama Korea, Fashion, Mahasiswa Universitas Al Asyariah Mandar. 


\section{PENDAHULUAN}

Drama Korea atau Korean Drama adalah drama yang diproduksi dalam bahasa Korea dengan format miniseri. Drama adalah fiksi atau cerita yanag dari sebuah gambaran hidup masyrakat Korea Selatan, drama Korea hadir pertama dalam siaran TV Indonesia sejak 2002 dan berjudul Endless Love, sejak saat itu sampai 2011 lebih 50 drama Korea yang tayang disiaran televisi Indonesia. Drama Korea juga hadir dalam cerita yang berepisode dari 16, dan 32 epesode terahir dengan durasi 40 menit bahkan mencapai 1 jam sehingga banyak watuk yang dibutuhkan untuk menonoton satu drama. Setelah banyak aktris dan aktor yang mampu mangambil dan menarik masyarakat yang ada di seluruh dunia. Kemampuan yang baik serta tampilan yang menarik para pemain drama Korea dapat mengembangkan industri yang ada di Korea dengan ditandai produk film, karakter dengan kedalaman yang baik naskah cerdas dengan bagian besar tergantung dari pola dasar.

Secara etimologi makna kata "fashion" berasal dari bahasa latin, factio, yang artinya membuat atau melakukan (Barnard 1996:11). Oxfrod En;glish Dictionary (OED) menyusun daftar arti berbeda dari kata fashion mulai dari "tindakan atau proses membuat", "potongan", "bentuk", "hingga tata cara bertindak" dan "berpakaian mengikuti konvensi". Makna fashion dapat diartikan kedalam kata benda dan kata kerja. Sebagai kata benda "fashion" berarti sesuatu seperti bentuk dan jenis, atau buatan terentu atau sebagai cara bertindak.Disini fashion juga bisa dipandang sebagai cara atau perilaku. Sebagai kata kerja fashion memiliki arti kegiatan atau membuat atau melakukan (Barnard1996). Jadi dapat disimpulkan bahwa fashion tidak hanya sekedar bagaimana kita mengenakan pakaian tetapi tata rias, gaya, aksesoris dan lain-lain masuk dalam kategori dari arti kata fashion.

Sejak dunia pefilman Korea naik daun di mancanegara, gaya busana dan kecantikan Korea ikut tersorot. Korea pun dijadikan patokan dalam urusan kecantikan. Artis dan aktor Korea secara tidak langsung mengambil peran dalam penyebaran fashion tren ala Korea Selatan. Hal itu dapat dikatakan berhasil karena kini gaya busana ala Korea Selatan merajalela di mana-mana. Online shop menjual berbagai pakaian dan aksesoris Korea, dan tidak hanya itu produk elektronik yang di pakai oleh idola mereka juga menjadi panutan mereka (Sumartono, 2013). Unik, colorfull, kasual dan inspiratif adalah beberapa ciri khas dari fashion ala orang Korea atau yang lebih dikenal dengan Korean Style. Hal ini menjadi salah satu alasan,mengapa Korean Style menjadi salah satu tren baru di masyarakat Indonesia, terutama di kalangan para remaja.

Ciri khas make up segar natural ala Korea lebih mengandalkan eye liner dan blush on. Pemilihan warna eye shadow juga cenderung berani, yakni warna 
terang, namun tidak terkesan berat pada pengaplikasiannya. Menonjolkan aplikasi blush on menghasilkan pipi yang semu.

Penampilan secara keseluruhan menunjukkan gaya muda dengan riasan ringan natural, namun berani bereksperiman. Gaya berbusana casual, lucu dengan pilihan warna yang menarik menjadi tren saat ini. Saat ini di kalangan remaja yang berkiblat pada pakaian Korea, pakaian yang sedang diminati remaja adalah kemeja syal dan kemeja sofie. Dengan kemeja syal yang terbuat dari kain rayon dan dipadu syal dengan corak berbeda, akan terlihat lebih elegan dan cute.

Jika dipadukan dengan celana jeans atau hot pants mini, kaki akan terlihat lebih panjang dan seksi. Cara berbusana seperti para aktor dan aktris pada drama Korea, para personil boyband, sebut saja Super Junior, dan girlband seperti SNSD, pada dasarnya sama seperti orang Asia pada umumnya, namun mereka lebih berani untuk mengeksplorasi dan berinovasi dengan segala hal yang bisa ditambahkan pada busananya.

Untuk busana para pria, bisa dibilang memiliki gaya yang lebih feminin. Tidak hanya dari jenis baju $V$-neck atau dengan belahan rendah, riasan wajah dan tata rambut membuat tampilan mereka tampak begitu feminin dan manis, bahkan hingga sepatu yang dikenakan pun berani memamerkan warna-warna terang. Sedangkan untuk perempuan, stocking tipis, setinggi paha, atau bahkan kaos kaki lucu menjadi item yang wajib untuk dikenakan. Untuk keseharian, mereka biasanya mengenakan busana sesuai dengan musim. Uniknya adalah walaupun mengenakan bawahan yang pendek dan agak terbuka, hampir semua perempuan di Korea memakai atasan yang ditutupi oleh cardigan atau mini blazer.

Hallyu seakan mewabah di berbagai negara di dunia, termasuk Indonesia. Joseph Nye menyebutkan Gelombang Korea adalah semakin populernya segala hal megenai Korea, seperti film, drama, msuic, masakan, hingga fashion. Kegemaran akan budaya Korea di mulai di Republik Rakyat Cina dan Asia tenggara pada akhir tahun 1990-an. Korean Wave (Gelombang Korea) atau hallyu dalam bahasa Korea adalah istilah yang digunakan untuk menamai tersebarnya budaya pop Korea secara global di banyak negara di dunia sejak tahun 1990an. Pada umumnya hallyu membuat banyak orang berbondongbondong mempelajari Bahasa Korea dan kebudayaan Korea.

Drama Korea merupakan penyebab dari mulainya gelombang Korea. Hallyu seakan mewabah di berbagai negara di dunia, termasuk Indonesia. Korean Wave melanda Indonesia dan membius masyarakat Indonesia khususnya remaja yang menjadi sasaran utama. Fenomena budaya ini mengingatkan kembali akan kegemaran masyarakat Indonesia menonton drama Amerika Latin atau yang dikenal dengan telenovela. 
Kegemaran masyarakat kita menonton tayangan drama Korea di televisi dibuktikan dengan ratting tinggi yang didapatkan oleh statisiun TV yang menayangkan drama Korea, meskipun drama tersebut bukan merupakan drama terbaru. Data yang di lansir oleh tabloid Bintang menyebutkan bahwa TV swasta beberapa waktu yang lalu telah menayangkan serial drama yang berjudul Full House pada slot super primetime secara stripping, dan tayang pada pukul 20.00 WIB. Di luar ekspektasi terhadap serial yang pertama kali tampil dan beberapa kali tayang di Indonesia kini meraih ratting dan share yang cukup banyak, dan menjadi hal yang luar biasa untuk program tayangan ulang. Pada episode terakhir mampu masuk ke dalam peringkat 20 besar dengan perolehan share sebanyak 9,4 juta. Siaran Indosiar menjadi siran TV pertama yang menayangkan serial Korea, bahkan sempat memberikan 3 slot yang dikhususkan untuk drama Korea pada siang hingga sore hari: pukul 12.00, 13.30 dan 16.30 dimana semua serial tersebut yang pertama kali tayang di Indonesia.

Proses penambahan slot pun terjadi di saat serial Crull Temptation telah sukses mencapai share rata-rata 19\%, kemudian make-up, fashion dan pernakpernik Korea menjadi konten penting dalam penggarapan serial tersebut. Gaya ala drama Korea yang bisa kita lihat yaitu pada sinetron remaja dimana pelajar yang ke sekolah menggunakan rok yang cukup pendek dengan kaos kaki yang panjang, bentuk kerah seragamnya seperti pelaut dan seringkali memakai rompi rajut walaupun cuaca yang sedang panas terik. Dengan seringnya drama Korea bermunculan di layar kaca, maka para pecinta drama Korea mulai merasa penasaran terhadap segala hal yang berbau drama Korea dan bukan hanya drama, musik, fashion, bahasa, ataupun produksi tetapi segala sesuatu yang berhubungan dengan Korea menjadi sangat populer.

Dalam perspektif kritis, Drama Korea tersebut merupakan alat pembentukan wacana untuk menguasai alam pikiran publik. Setiap subjek sebagai yang memproduksi wacana, jika hendak bertahan dalam merebut pengaruh, harus memiliki "akar kuat" yang masuk ke dalam isi pikiran publik. Disinilah wacana diproduksi, didistribusi, lalu dikonsumsi oleh khalayak, lalu menjadi bagian yang tak terpisahkan dari khalayak, bahkan menjadi anutan halayak (Hamdan, 2019). Serba Korea telah menguasai wacana hiburan dan membentuk ideologi tersendiri dan mempengaruhi cara bertindak seseorang, yang penulis sebut sebagai ideologi serba Korea.

Adanya ketertarikan terhadap program siaran tersebut dapat memberikan gambaran bahwa penonton akan senantiasa menyaksikan setiap penayangannya. Hal ini didukung oleh meningkatnya frekuensi penayangan dan meningkatnya frekuensi menonton. Sehingga diprediksi acara drama Korea dapat menyebabkan perubahan perilaku ber-fashion pada remaja. Pengaruh drama Korea terhadap fashion menjadi fenomena menarik untuk dibahas lebih 
dalam terutama pengaruhnya terhadap mahasiswa universitas Al Asyariah Mandar.

\section{METODE PENELITIAN}

Jenis penelitian yang digunakan adalah penelitian kuantitatif dengan pendekatan penelitian korelasi (corelation), yaitu penelitian yang bermaksud untuk mengetahui ada tidaknya hubungan atau pengaruh antara dua variabel. Variable X adalah menonton drama Korea dan variabel Y adalah fashion mahasiswa Universitas Al Asyariah Mandar.

Populasi dalam penelitian ini adalah Mahasiswa FISIP Universitasd Al Asyariah Mandar Angkatan 2017 yang berjumlah 60 orang. Teknik sampling yang digunakan adalah non-probablity sampel. Data dikumpulkan menggunakan dua teknik pengumpulan data yaitu kuisioner dan dokumentasi.

Data yang terkumpul dianalisis menggunakan dua teknik yaitu: pertama, analisis univariate untuk mengetahui distribusi sebagai frekuensi dan presentasi dari masing-masing variabel yang diteliti, baik bebas maupun terikat (notoatmidjo, 2010); kedua, analisis bivariate untuk menguji beda dua sampel bebas nonparametik chi square pada derajat kepercayaan 95\% (a=0,5).

\section{HASIL PENELITIAN}

\section{Karakteristik Responden Penelitian}

Berdasarkan hasil analisis data, maka propil responden yang diproleh yaitu:

\section{Tabel 1}

Jenis Kelamin

\begin{tabular}{|c|l|c|c|}
\hline No & Jenis Kelamin & Jumlah & $\%$ \\
\hline 1 & Perempuan & 55 & $92 \%$ \\
\hline 2 & Laki-laki & 5 & $8 \%$ \\
\hline & Total & 60 & 100 \\
\hline
\end{tabular}

Hasil dari data yang mengenai rasa suka respoden terhadap fashion yang menyangkut tentang drama Korea sehingga hasi dari penelitian dilampirkan dan dapat dikenali seberapa rasa suka atau seberapa banyak responden terhapa fhsion Drma Korea dengan cara melihat tabel dibawah ini :

\section{Tabel 2}

\section{Klarifikasi Suka dan Tidak}

(Hasil olahan data, 2020)

\begin{tabular}{|l|l|l|l|}
\hline No & Klarifikasi Suka dan Tidak Suka & Jumlah & $\%$ \\
\hline
\end{tabular}




\begin{tabular}{|l|l|c|c|}
\hline & fashion Drana Korea & & \\
\hline 1 & Suka Fashion Drama Korea & 46 & $77 \%$ \\
\hline 2 & Tidak Suka Fashion Drama Korea & 14 & $23 \%$ \\
\hline & Total & 60 & $100 \%$ \\
\hline
\end{tabular}

Untuk mengetahui pengaruh variabel $\mathrm{X}$ terhadap variabel $\mathrm{Y}$, data di atas kemudian diolah menggunakan rumus regresi pada aplikasi SPSS 21. Hasil yang didapatkan adalah sebagai berikut:

\section{Tabel 3}

Model Summary

(Hasil olahan data, 2020)

\begin{tabular}{|l|l|l|l|l|}
\hline Model & R & R sguare & $\begin{array}{l}\text { Adjusted R } \\
\text { Sguare }\end{array}$ & $\begin{array}{l}\text { Std. Error of } \\
\text { the Estimate }\end{array}$ \\
\hline 1 & $0,578^{a}$ & 0,334 & 0,323 & 6,981 \\
\hline
\end{tabular}

a.predictors: (Constant), intensitas

Tabel di atas menjelaskan tentang besarnya nilai pengaruh yang ada dilapangan dengan $\left(\mathrm{R}^{2}\right)$, yaitu sebesar 0,578 . Sedangkan pada kolom $\mathrm{R}$ Square menjelaskan besarnya persentase (\%) pengaruh variabel independen (X) terdapat variabel dependent (Y) yang disebut dengan koefisien determininas. Dari tadel diperoleh nilai koifisien determinasi $\left(\mathrm{R}^{2}\right)$ sebesar 0,334 artinya bahwa pengaruh variabel (Intensitas) terdapat variabel (fashion) adalah sebesar $33 \%$, sedangkan sisanya dingaruhi oleh variabel lain diluar penelitian.

Tabel 4

ANOVA

(Hasil olahan data, 2020)

\begin{tabular}{|l|l|l|l|l|l|}
\hline Model & $\begin{array}{l}\text { Sum of } \\
\text { Square }\end{array}$ & Df & $\begin{array}{l}\text { Mean } \\
\text { Square }\end{array}$ & F & Siq \\
\hline $\begin{array}{l}\text { Rekression } \\
\text { Residual } \\
\text { Total }\end{array}$ & $\begin{array}{l}1419,855 \\
2826,329\end{array}$ & 1 & 1419.855 & 29,137 & $.000^{\mathrm{b}}$ \\
4246,183 & 59 & 48.730 & & \\
\hline
\end{tabular}

a. Dependen Variabel: fashion

b. Predictor: (Constant), Intensitas (Menonton Drama Korea)

Tabel ANOVA fungsinya adalah untuk menjelaskan apakah ada pengaruh yang signifikan antara variabel intensitas $(X)$ terdapat variabel 
fashion (Y) dari output tersebut nilai Fhitang $=29.137$ dengan tingkat siknifikasi < produksi $(0,000<0,05)$ maka model rekresi dapat digunakan untuk memperole variabel fashion $(\mathrm{Y})$.

\section{Tabel 1.2 \\ COEFICIENT}

(Hasil olahan data, 2020)

\begin{tabular}{|l|c|l|l|l|l|}
\hline \multirow{2}{*}{ Model } & \multicolumn{2}{|c|}{$\begin{array}{c}\text { Unstandardized } \\
\text { Coefficients }\end{array}$} & $\begin{array}{c}\text { Standardized } \\
\text { Coefficients }\end{array}$ & T & Sig. \\
\cline { 2 - 4 } & B & Std. Error & Beta & & \\
\hline (Constant) & 13,466 & 12,935 & & 1,041 & 0,302 \\
INTENSITAS & 1,107 & 0,205 & 0,578 & 5,398 & 0,000 \\
\hline
\end{tabular}

a. Dependent Variable: FASHION

Pada tabel (Coefficientsa), pada kolom B nilai Constant (a) adalah 13,466, sedangkan nilai Intensitas (b) adalah 1,107, sehingga persamaan regresi dapat ditulis:

$$
\begin{aligned}
& Y=\alpha+b X_{1} \\
& (Y=13,466+1,107)
\end{aligned}
$$

Koefisien (b) dinamakan koefisien arah regresi yang menyatakan perubahan rata-rata variabel $Y$ untuk setiap perubahan variabel X sebesar satu satuan. Perubahan ini merupakan pertambahan bila (b) bertanda positif (+) dan penurunan bila (b) bertanda negatif. Sehingga dari persamaan tersebut dapat diterjemahkan sebagai berikut:

- Persamaan regresi ini menampilkan uji signifikansi dengan uji yaitu untuk mengetahui apakah ada pengaruh yang signifikan antara variabe 1 Intensitas (X) secara parsial terhadap variabel Fashion (Y).

- Dari output di atas (tabel coefficients) diketahui nilai t hitung $=5,398$ dengan nilai signifikansi $0,000<0,05$ maka Ho ditolak, artinya: Ada pengaruh yang signifikan antara variabel Intensitas $(\mathrm{X})$ terhadap variabel Fashion (Y).

Untuk mengetahui persamaan regresinya berikut perhitungannya. Diketahui nilai constant-Nya (konstanta) adalah 13,466 dan nilai Intensitasnya adalah 1,107. dari keterangan tersebut kita dapat memperoleh Persamaan regresi-nya sebagai berikut: 


$$
\mathrm{Y}=13,466+1,107 \mathrm{X}
$$

a. Konstanta $(\mathrm{a})=13,466$

Artinya: apabila Intensitas Menononton Darama Korea $\left(\mathrm{X}_{1}\right)$ sama dengan nol (tidak ada perubahan), maka Fashion Mahasiswa Unasman (Y) sebesar 13,466

a. Koefisien regresi Intensitas $(b)=+1,107$

Koefisien regresi positif (searah), sebesar 1,107 artinya, jika Intensitas (X) meningkat sebesar 1 satuan, maka Fashion (Y) akan meningkat sebesar 1,107. artinya; jika Intensitas meningkat sebesar 1,107 maka Fashionnya juga akan meningkat sebesar 1,107 .

\section{KESIMPULAN}

Terdapat pengaruh antara menonton drama Korea terhadap fashion mahasiswa Universitas Al Asyariah Mandar. Didapatkan adanya pengaruh secara signifikan sebanyak 33\%, sedangkan $77 \%$ dipengaruhi oleh faktor lain di luar penelitian ini. Drama Korea berisi sepenuhnya tentang budaya Korea, sehingga banyaknya waktu yang dicurahkan untuk menonton drama Korea dapat mempengaruhi secara kognitif bahkan efektif. Pikiran dan perilaku yang kita lakukan sehari-hari merupakan gambaran atau hasil dari asupan informasi yang terserap ke dalam seseorang. Seperti tontonan, dan kebiasaan sehari-hari. Banyaknya waktu yang dihabiskan untuk menonton drama Korea membawa pengaruh terhadap fashion seperti gaya berbusana dan make up.

\section{SARAN}

Dengan dilakukannya penelitian ini, peneliti berharap para pembaca mendapat gambaran tentang bagaimana sebuah tontonan dapat memengaruhi kita. Penelitian ini diharapkan menjadi salah satu referensi untuk penelitian selanjutnya yang tertarik meneliti lebih lanjut tentang pengaruh Drama Korea. Peneliti juga berharap penelitian ini bisa memotivasi adik-adik untuk melanjutkan penelitian ini agar lebih sempurna lain.

\section{DAFTAR PUSTAKA}

Wikipedia. Hallyu. https://id.wikipedia.org/wiki/Hallyu , diakses pada tanggal 22 Februari 2020

Barnard, Marcom. 2011. Fashion sebagai Komunikasi (Cara Mengkomunikasikan Identitas, Sosial, Seksual, Kelas dan Gender) Jalasutra. Yogyakarta.

Hamdan. (2019). Wacana dalam Perspektif Norman Fairclough. Jurnal Komodifikasi, Volume 7(1). 
Majid, Abdul dan Dian Andayani. 2010. Pendidikan Karakter Dalam Perspektif Islam, Bandung: Insan Cita Utama.

Sumartono, Hani Astuti. 2013. Terpaan Drama Korea Dan Perilaku Fashion Di Kalangan Mahasiswi Fikom Ubhara Jaya.

Mansur, Ahmad. 2016. Pendidikan Karakter Berbasis Wahyu, Jakarta: Gaung Persada.

Sudijono, Anas. 2012. Pengantar Statistik Pendidikan, Jakarta: PT Raja Grafindo,

Departemen Pendidikan Dan Kebudayaan, 2005. Kamus Besar Bahasa Indonesia. Jakarta. Balai Pustaka. 